\title{
IdeAs
}

Idées d'Amériques

$17 \mid 2021$

Villes et culture dans les Amériques

\section{Beyond Repair: Resistance and Respectability Politics in Colombia}

\section{Anthony Dest}

\section{(2) OpenEdition \\ 12 Journals}

Electronic version

URL: https://journals.openedition.org/ideas/10993

DOI: 10.4000/ideas.10993

ISSN: 1950-5701

\section{Publisher}

Institut des Amériques

\section{Electronic reference}

Anthony Dest, "Beyond Repair: Resistance and Respectability Politics in Colombia", IdeAs [Online], 17 | 2021, Online since 01 March 2021, connection on 04 June 2021. URL: http://journals.openedition.org/ ideas/10993 ; DOI: https://doi.org/10.4000/ideas.10993

This text was automatically generated on 4 June 2021 .

\section{(c) (i) (9)}

IdeAs - Idées d'Amériques est mis à disposition selon les termes de la licence Creative Commons Attribution - Pas d'Utilisation Commerciale - Pas de Modification 4.0 International. 


\title{
Beyond Repair: Resistance and Respectability Politics in Colombia
}

\author{
Anthony Dest
}

I greatly appreciate the thoughtful conversations about this article with Daniel Campo, Sofia Garzón, Óscar Pedraza, Luciane Rocha, Gimena Sánchez-Garzoli, Shreyas Sreenath, Elizabeth Velásquez Estrada, and Coletta Youngers, as well as the comments from Laura Cahier and Laetitia Braconnier Moreno.

\begin{abstract}
In every era the attempt must be made anew to wrest tradition away from a conformism that is about to overpower it. Walter Benjamin, “Theses on the Philosophy of History" (1940)
\end{abstract}

\section{Rumors and Hummers}

1 In a conference room a few blocks from the White House, an official from the Colombian Embassy stressed that the victim defended drug traffickers and was known to drive around Cali in a Hummer. ${ }^{1}$ The person in question - Hernan Darío Escobar, a Colombian attorney - was targeted in a drive-by shooting in May 2011. The Embassy official seemed to imply that Hernán Darío Escobar was not a noble social leader or a champion of the downtrodden - he got what he deserved. As Escobar lay dying in a hospital, she and other officials from the Colombian government tried to avert a public relations fiasco by spreading the narco-narrative amongst their extensive contacts in the U.S. Congress. They were in the years-long process of trying to push through the U.S.-Colombia Free Trade Agreement (FTA), and the murder of another social leader threatened to undermine their plans.

2 At the human rights organization where I worked at the time, we rushed to find the facts about the murder and place them within the context of widespread violence against trade unions and social movement activists in Colombia. The rumors emanating from the Colombian Embassy were intended to contradict our initial press release 
about the assassination attempt. As dutiful activists, we were familiar with the government's efforts to downplay the murder of social leaders by sullying their names. By framing the events as an assault on the rights of the sugarcane cutters that Escobar represented pro bono, we argued that this instance of violence meant something.

This experience has troubled me for nearly a decade. Of course, the Embassy official's attitude about the murder of a human being was distasteful, but it was not surprising. Despite the Colombian Embassy's pleas for patience and due process when we denounced murders and death threats, they always seemed to "know" when a dogooder had a bad side. Former Minister of Defense Luis Carlos Villegas said as much in 2017, when he attributed the "immense majority" of murders of social leaders to "disputes about property lines, skirts, demands, or fights over illicit revenues" ( $E l$ Espectador, 2017). These kinds of slanderous remarks represent an effort to dismiss the possibility that activists are targeted because of their political work or that the violence might be associated with the continuity of the armed conflict. The state's hostile disposition towards activists all but guarantees dead-end investigations and impunity in most cases of violence.

My problem, however, related to how I played into the state's framing of the violence. Instead of rejecting the fact of violence and its use as a means for legitimizing state power, I upheld the respectability politics implicit in liberal forms of human rights activism. Black feminists have long critiqued the limits of respectability politics. Rather than seeking recognition or access by embodying the model citizen through the politics of respectability, Cohen suggests that "a politics of deviance" might hold more "transformative potential [...] for radically improving the lives and possibilities of those most vulnerable in Black communities" (Cohen C., $2004: 30$ ). In order for Escobar's death to matter to policymakers in the United States and Colombia, however, his reputation needed to be untarnished. An adherence to respectability politics guarantees that some lives and issues are worth fighting for while others are beyond the pale, and, in this case, it allowed for the state to control the conversation.

\section{Deterring Resistance}

These kinds of smear campaigns rely on the power of respectability politics to deter resistance. They locate the "criminal" as a subject beyond repair, and the organizations that struggle in solidarity with the supposed "criminals" are guilty by association. Colombia's armed conflict has long served as a pretext for stigmatizing the reputations of activists. By merely insinuating that so-and-so was linked to a guerrilla group, that person becomes indissociable from an ever-growing list of damning labels: "communist," "terrorist," "narco-terrorist," "Castro-Chavista," etc. Public officials with long histories of participating in electoral politics are not immune, and struggles that center individualistic forms of leadership are particularly susceptible to these kinds of stigmatization.

The effects of these dynamics are especially difficult for people with lower profiles. For many activists, the consequences for being accused of having ties to an armed group or drug traffickers can be fatal. The rising body counts on the websites of human rights organizations attest to the scale of violence. Accusations can also lead to prison time. Over the course of the last ten years, three of my close colleagues from the Black Communities Process (Proceso de Comunidades Negras, PCN) spent years in jail based on 
false allegations that they supported guerrilla groups. It is hard to overstate the amount of energy dedicated to clearing their names with the hope of building a robust solidarity campaign to support them, their families, and their communities. However, for many potential advocates, the burden of confronting the stigma of possible guilt proved too great, and they picked up another less compromising cause to support.

In that sense, human rights advocates can become an "active agent in the war of silencing" (Taussig M., 1989 : 20). In the context of war, the chimerical demand for clear-cut cases of perfectly innocent victims obstructs the potential of engaging with the complicated realities that people confront. In their analysis of how victims become neutralized as political subjects in the liberal "post-conflict" imagination, Pedraza and Álvarez argue:

Although in practice the ways in which victims define their experiences are not reducible to homogeneous or static categories, the political and legal experiences of what has become known as the "victim" have generally been reduced to a series of moral elements that vacate the political character of their history and subsume them into a narrative of trauma, suffering, and pain.

(Pedraza ó. \& Álvarez C., 2016: 175)

8 This morality is especially clear in areas of the country like northern Cauca that are heavily affected by violence and drug trafficking. For example, after the murder of an indigenous person in a coca-growing town in September 2020, an activist associated with the indigenous movement made sure to indicate in their public denunciation that the victim "was not an indigenous leader." The disclaimer implied that the murder may have mattered more if the victim was an indigenous leader. It also ostensibly ensured that the movement could avoid the dangers of claiming a potential criminal as one of their own. As an abolitionist, Gilmore addresses this "problem of innocence" the following way: "To insist on innocence is to surrender politically because 'innocence' evades a problem abolition is compelled to confront: how to diminish and remedy harm as against finding better forms of punishment" (Gilmore R., $2017: 236)$. As such, these kinds of disclaimers and the narratives of pure victimhood contribute to the dominant discourse of just/unjust violence with all of its moralistic and punitive underpinnings. In the words of Taussig, this political surrender "is more than the production of silence. It is silencing, which is quite different" (Taussig M., 1989: 14).

\section{Beyond Respectability Politics}

Respectability politics silences. Escobar's murder ultimately faded into the background of our work at the human rights organization. We did not stop speaking out against violence, but we did focus on other cases that might provide us with a clearer political advantage. The decision about which cases to take on meant sifting through countless examples to find something winnable and unequivocal, which also meant engaging with the forms of interpellation that determine respectability and criminality. Meanwhile, the cases with the sketchy details that bordered on the "criminal" often languished in impunity. Although this strategy makes a certain degree of traction with institutions possible, it has the effect of making many more cases off limits. Rejecting respectability politics may foreclose the cherished access to institutions that constitutes the basis of mainstream human rights activism. However, rejecting respectability politics also contains the possibility of disrupting a political system premised upon the use of violence against the subjects it constructs as disposable. 


\section{BIBLIOGRAPHY}

Benjamin, Walter, “Theses on a Philosophy of History", in Hannah Arendt (ed.), Illuminations: Essays and Reflections, New York, NY: Schocken Books, 2007, p. 253-264.

Cohen, Cathy, "Deviance as Resistance: A New Research Agenda for the Study of Black Politics", Du Bois Review, vol. 1, 2004, p. 27-45.

El Espectador, “Asesinatos de líderes son por 'líos de faldas': ministro de Defensa”, El Espectador, 17 December 2017, https://www.elespectador.com/noticias/politica/asesinatos-de-lideres-sonpor-lios-de-faldas-ministro-de-defensa/, accessed on 13 October 2020.

Gilmore, Ruth Wilson, “Abolition Geography and the Problem of Innocence”, in Gaye Theresa Johnson and Alex Lubin (eds.), Futures of Black Radicalism, London, Verso, 2017, p. 225-240.

Pedraza, Óscar and Camilo Álvarez, "Maquinarias transicionales y neutralización política de las víctimas en Colombia", in Neyla Graciela Pardo Abril and Juan Ruiz Celis, Víctimas, memoria y justiciar: aproximaciones latinoamericanas al caso colombiano, Bogotá, Colombia, Universidad Nacional de Colombia, 2016.

Taussig, Mick, “Terror as Usual: Walter Benjamin's Theory of History as a State of Siege”, Social Text, $\mathrm{n}^{\circ} 23,1989$, p. 3-20.

\section{NOTES}

1. This article is based on my experience working at a human rights non-governmental organization (NGO) in Washington, DC between 2010 and 2012. Since then, I have continued to work closely with human rights activists on a variety of issues as a scholar and as part of my political commitments.

\section{AUTHOR}

\section{ANTHONY DEST}

Anthony Dest is Assistant Professor of Anthropology at Lehman College. His doctoral dissertation, After the War: Violence and Resistance in Colombia (University of Texas, Austin), was recognized as the Best Dissertation of 2019 by the Peace and Justice Studies Association. His research has been supported by fellowships from the National Science Foundation, the Social Science Research Council, and the Inter-American Foundation. anthony.dest@lehman.cuny.edu. 